\title{
PARAPLEGIA
}

\section{Index to volume 19 (198I)}

\section{Subject index}

\section{Ambulation}

Spinal cord lesions and lower extremity bracing: an overview and follow-up study, by Mikelberg and Reid 379

\section{Aneurysmal Bone Cyst}

Aneurysmal bone cyst of a vertebral body with acute paraplegia, by Shacked et al. 294

\section{Anticoagulants}

Low dose heparin prophylaxis for deep venous thrombosis in acute spinal cord injury patients: a controlled study, by Frisbie and Sasahara 348

Prophylactic anticoagulant therapy in patients with spinal cord injury, by $\mathrm{El}$ Masri and Silver 334

\section{Aortic Aneurysm}

Atraumatic ischaemic myelopathy, by Kewalramani and Katta 337

\section{Arachnoiditis}

Non-traumatic adhesive arachnoiditis as a cause of spinal cord syndromes. Investigation of 507 patients, by Jenik et al. I40

Bedbrook, Sir George Montario

Profile, by Griffiths 263

\section{Bladder Neoplasms}

Bladder cancer after spinal cord injury, by El Masri and Fellows 265

\section{Braces}

Spinal cord lesions and lower extremity bracing: an overview and follow-up study, by Mikelberg and Reid 379

\section{Calcium Metabolism}

Reduction of hypercalciuria in tetraplegia after weight-bearing and strengthening exercises, by Kaplan et al. 289

\section{Children}

Permanent flaccid paraplegia in children with thoracic spinal cord injury, by Boltshauser et al. 227

\section{Condom Sheaths}

Complications of external condom drainage, by Golji $\quad 189$

A new device for fastening the condom sheath, by Brooks and Spector 187

\section{Contracture}

The prevention of shoulder pain and contracture in the acute tetraplegia patient, by Scott and Donovan 313

\section{Depression}

Depression in spinal cord injured patients, by Howell et al. 284

Psychological response to acute spinal cord injury: an epidemiological study, by Bracken et al. 27I

\section{Diagnosis}

Computed tomography of the spine and spinal cord; limitations and applications, by Hachen 155

Is the pattern of neurological damage of diagnostic value in the radiological assessment of acute cervical spine injury? by Scher 248

Unrecognised fractures and dislocations of the cervical spine, by Scher 25

\section{Ejaculation}

Reflex ejaculation under vibratory stimulation in paraplegic men, by Brindley 299

\section{Epidemiology}

A survey of non-traumatic paraplegia, by Watson 107

\section{Exercise Therapy}

Reduction of hypercalciuria in tetraplegia after weight-bearing and strengthening exercises, by Kaplan et al. 289

\section{Fractures}

Lower extremity fractures in patients with spinal cord injury, by Freehafer et al. 367 


\section{Hand Surgery}

Early complications of key grip hand surgery for tetraplegia, by Smith I23

Report from International Federation of Societies for Surgery of the Hand: from the Committee on Spinal Cord Injuries I980, by Moberg 386

\section{International Year for Disabled Persons 198I \\ by Hachen 63 \\ by Weiss 65}

\section{Intervertebral Disc Displacement}

Paraplegia as a sequela to dorsal disc prolapse, by Terry et al. III

Paraplegia due to intervertebral disc lesions: a review of 57 operated cases, by Ravichandran and Frankel I33

\section{Intestinal Obstruction}

Acute gastric dilatation as a relatively late complication of tetraplegia due to very high cervical cord injury, by Sutton et al. I7

Delayed gastric emptying after vagotomy and drainage in the spinal cord injury patient, by Osteen and Barsamian 46

Late ileus in paraplegia, by Watson $\mathrm{I}_{3}$

Prolonged ileus with acute spinal cord injury responding to metaclopramide, by Miller and Fenzl 43

\section{Kidney Calculi}

Clinical and experimental studies with oral aluminium hydroxide, by Burr and Nuseibeh I 78

Urolithiasis in patients with spinal cord injury, by Nikakhtar et al. 363

\section{Marriage}

The impact on marriages of adult-onset paraplegia, by Abrams 253

Mortality

Analysis of mortality of patients after cervical spine trauma, by Kiwerski et al. 347

\section{Neoplasms}

Aneurysmal bone cyst of a vertebral body with acute paraplegia, by Shacked et al. 294

Bladder cancer after spinal cord injury, by $\mathrm{El}$ Masri and Fellows 265

Non-traumatic acquired tetraplegia: case report, by Pool 164

Paraplegia due to spinal epidural neoplasia, by van Woerkom-Eijkenboom and Braakman IOO

\section{Neurological Sequelae}

Is the pattern of neurological damage of diagnostic value in the radiological assessment of acute cervical spine injury? by Scher 248
Morphological and histochemical correlation of recovery after spinal transection in rat, by Sahgal et al. I

Neurological improvement in traumatic injuries of cervical spinal cord, by Kiwerski and Weiss $3 \mathrm{I}$

Post-traumatic acute anterior spinal cord syndrome, by Foo et al. 20I

\section{Non-Traumatic Paraplegia}

Non-traumatic acquired tetraplegia: case report, by Pool 164

Non-traumatic adhesive arachnoiditis as a cause of spinal cord syndromes. Investigation on 507 patients, by Jenik et al. 140

Paraplegia due to intervertebral disc lesions: a review of 57 operated cases, by Ravichandran and Frankel 133

Paraplegia as a sequela to dorsal disc prolapse, by Terry et al. II I

Paraplegia due to spinal epidural neoplasia, by van Woerkom-Eijkenboom and Braakman IOO

Sarcoidosis as a cause of transverse myelitis: case report by Baum et al. $\quad 167$

A survey of non-traumatic paraplegia, by Watson 107

\section{Osteitis Deformans}

Spinal cord function in Paget's disease of bone, by Ravichandran 7

\section{Pressure sores}

The 'hammock' effect in wheelchair cushion covers, by Denne 38

Prevalence and incidence of pressure sores in acute spinal cord injuries, by Richardson and Meyer 235

\section{Psychological reactions}

Depression in spinal cord injured patients, by Howell et al. 284

Psychological response to acute spinal cord injury: an epidemiological study, by Bracken et al. $27 \mathrm{I}$

\section{Sarcoidosis}

Sarcoidosis as a cause of transverse myelitis: case report, by Baum et al. $\quad$ I67

\section{Shoulder Pain}

The prevention of shoulder pain and contracture in the acute tetraplegia patient, by Scott and Donovan 313

\section{Somatosensory Cortex}

Somatosensory cerebral evoked potentials in spinal cord diseases, by Grüninger and Ricker 206

Somatosensory evoked potentials in spinal cord injured patients, by Kaplan and Rosen I 8 
Sports Injuries

Cervical spine injuries resulting from collision sports, by Kewalramani and Krauss 303

\section{Syringomyelia}

Ascending cystic degeneration of the cord after spinal cord injury, by Watson 89

Neuroradiological evaluation in progressive post-traumatic cystic myelopathy (PPCM), by Seibert et al. $\mathbf{1} 86$

Post-traumatic syringomyelia (cystic myelopathy), by Griffiths and McCormick 8I

Progressive late post-traumatic syringomyelia, by Rossier et al. 96

Syringomyelia as a sequel to traumatic paraplegia, by Williams et al. 67

\section{Thromboembolism}

Low dose heparin prophylaxis for deep venous thrombosis in acute spinal cord injury patients: a controlled study, by Frisbie and Sasahara 348

Prophylactic anticoagulant therapy in patients with spinal cord injury, by El Masri and Silver 334

\section{Tomography, X-Ray Computed}

Computed tomography of the spine and spinal cord; limitations and applications, by Hachen I55

\section{Urinary Tract}

Antiseptic and antibiotic resistance in gramnegative bacteria causing urinary tract in- fection in spinal cord injured patients, by Stickler et al. 50

Antistriated muscle-antibodies during clinical dysreflexia: case report, by Ram $\quad 127$

Bladder cancer after spinal cord injury, by El Masri and Fellows 265

Clinical and experimental studies with oral aluminium hydroxide, by Burr and Nuseibeh 178

Complications of external condom drainage, by Golji I89

Mucosal histology following prolonged use of the Urovac: a suction operated urinal, by Keane 22

A new device for fastening the condom sheath, by Brooks and Spector 187

The significance of antibody coated bacteria in neuropathic bladder urines, by Lindan 216

Some observations on the activity of three antiseptics used as bladder irrigants in the treatment of urinary tract infection in patients with indwelling catheters, by Stickler et al. 325

Urolithiasis in patients with spinal cord injury, by Nikakhtar et al. $\quad 363$

\section{Wheelchairs}

Energy cost and cardiopulmonary responses for wheelchair locomotion and walking on tile and on carpet, by Glaser et al. 220

The 'hammock' effect in wheelchair cushion covers, by Denne 38

Young, Dr John

Profile, by Carter I3I

\section{Author index}

(D) indicates a discussion of a paper at a meeting

Abrams, K. S. 253

Alba, A. I67

Barbenel, J. C. 320

Barsamian, E. M. 46

Baum, J. I67

Becker, R. N. 367

Bentley, R. I7

Boltshauser, E. 227

Braakman, R. IOO, I72(D)

Bracken, M. B. 27 I

Brindley, G. S. 299

Brooks, M. E. $\quad 187$

Bucher, H. U. 227
Bunni, N. H. 325

Burke, - I70(D)

Burr, R. G. I78, I85(D)

Chawla, J. C. 50, 325

Chrostowska, T. 323, 347

Denne, W. A. 38

Donovan, W. H. 313

Dreisbach, J. N. $\quad$ I86

Dyro, F. 96

Edgar, R. E. $\quad$ I 86

El Masri, W. S. I85(D), 265 